\title{
Catching the Runaway Train Innovation Management in Russian Railways
}

\author{
Thomas Thurner', Mikhail Gershman²
}

\begin{abstract}
This paper studies the innovation strategy of Russian Railways, the biggest transport company in the world. Russian Railways has chosen a strategy of international science, technology and innovation (STI) cooperation outside their own network. This strategy is a novel approach for Russian State-owned enterprises (SOE). Based on the analysis of innovation development program and interviews with managers, the paper studies the company's experience with the chosen strategy. Thereby, the paper enhances the understanding of innovation processes in major public service companies which are crucial for the socio-economic processes inside and outside national boundaries.
\end{abstract}

Keywords: innovation management; strategy; railways; state-owned enterprises; science and technology cooperation; russia. 


\section{Introduction}

The expansion of the knowledge base is vital for sustainable economic growth (see papers in endogenous growth literature like Romer, 1990; Aghion and Howitt, 1990). Such knowledge generation processes are mostly a collective action involving a wide number of heterogeneous actors (e.g. Roy, Sivakumar and Wilkinson 2004) and provide companies with an efficient way to upgrade products or services in an ever faster changing technological environment (Nelson and Winter, 1982, von Hippel 1988; Rosenberg, 1994; Niosi 1999).

The innovation literature to this day focuses heavily on knowledge flows along one's own value chain (customers, users, competitors and suppliers) (Chesbrough 2003; Gassmann 2006; Laursen and Salter 2006; Piller and Walcher 2006). Such positions turn a blind eye on the importance of the heterogeneity of knowledge sources for innovation performance (Porter 1990; Prahalad and Hamel 1990; Hagedoorn and Schakenraad 1994). Previous contributions mention the gap on knowledge coming from outside existing networks (see, for example, Enkel and Gassmann 2010), especially as a tool to overcome transnational differences by accumulating experience in cross-border collaboration (Barkema et al. 1997). Such knowledge transfer processes are not an easy task though. Firms rely on sufficient absorptive capacity when cooperating with external partners. To achieve the necessary sophistication, in-house R\&D units need to cooperate on a very high level (Cohen and Levinthal 1990). History is full of companies which once were technology leaders, but over time fell behind and struggled to find their position in an ever-changing environment (Here, Kodak serves as a recent example). Most contributions study the capabilities required in order to remain competitive in rapidly changing industries (Leonard-Barton 1992; Teece et al. 1997; Teece 2007; Eisenhardt and Martin 2000; Zollo and Winter 2002; Wang and Ahmed 2007) or factors for sustaining corporate success and continual renewal and innovation (Brown and Eisenhardt 1997). What is absent is research on the catch-up process of large companies to regain the position of technology leadership. These companies have two strategy choices: engage in own R\&D or acquire best technologies and imitate new products. The last option often appears in the literature as 'imitation strategy' (Schewe 1996) and has actively been discussed in line with a nation's technology catch-up processes. See, for example, Mansfield (1988) on Japanese advantage on innovations based on external technologies, Chiang (1989), Chen (2009) on Taiwan, Dobson and Safarian (2008) on China, Amsden (1989), Choi (1989) or Kim (1997) on Korea.
This paper studies innovation in Russian Railways, the world's largest transport company. It gives insights into the organizational structures and the technology management processes through which Russian Railways returned from simple high-tech imports to being a source of technological growth and development for Russia. This paper also provides a rare opportunity to study innovation management processes in public service companies. The low number of contributions discussing these companies is surprising, as they provide services for large parts of a country's population. The paper by Malagas et al. (2013) in this journal is a noteworthy exception. These social innovations, that directly influence living standards of the population, might be more urgent for the developing countries than hightechnology products exported abroad. Additionally, service companies may act as important producers for innovations (the way Russian Railways does) stimulating local innovation activities.

\section{Research question and methodology}

Innovation management and international R\&D cooperation of Russian SOEs have largely remained a mystery. In the recent years, the innovation development programs of Russian SOEs shed light on their strategies and processes. The initiative was launched in August 2010 and serves as the preferred policy tool of the Russian government to stimulate the innovation activities of the 47 largest SOEs ${ }^{3}$ whose overall share in the Russian industrial turnover accounted for more than $20 \%{ }^{4}$

In addition, the working group on Private-Public Partnership Development in innovation was created which included representativesfrom thegovernment,ministries,corporations, universities, and the Russian Academy of Sciences to make tactical decisions on innovation strategies of SOEs. ${ }^{5}$ These innovation strategies include new product development, modernization of equipment, commercialization of technologies, cooperation with universities, R\&D institutions and SMEs, participation in Russian technology platforms, and international collaborations.

\footnotetext{
${ }^{3} / 3$ companies were added to the existing list in 2012 .

${ }^{4}$ Over one third of these SOEs belong to the defence industry.

${ }^{5}$ Since 2012 this function has been performed by the Interministerial Commission on Technological Development under the Presidium of the Presidential Council for Economic Modernization and Innovative Development.
} 
Very few Russian SOEs actually access knowledge and technologies through international collaboration, and the number of companies using high-end developments in their production processes is even smaller. Russian Railways, the world's largest transport organization, struggles with outdated physical infrastructure and needed to find a quick solution to close their widening technology gap. Despite the company's history of a innovation initiator and the company's far reaching mission of increasing the country's level of production, its technology gap which opened up since the late 1980s needed immediate attention. The company also has a high social responsibility and is an instigator of economic development. Besides partnerships with Russian companies, Russian Railways has chosen a strategy of international science, technology and innovation (STI) cooperation outside their own network. Their way to regain initiatives over its innovation activities provides a unique opportunity to study if and how Russian SOEs can benefit from both knowledge transfer and common knowledge creation with international technology leaders.

The paper is based on the analysis of the innovation development program of Russian Railways and interviews with company's top-managers responsible for technology and innovation. Interviews lasted $45 \mathrm{~min}$ to one hour.

\section{About the company: Russian Railways}

Russian Railways is the largest transport company in the world with over I billion passengers, I.3 billion tons of cargo per year and about I million employees. Also the railway net is among the largest in the world and accounts for $85 \%$ of freight transport in the country (excluding pipeline transportation). Due to Russia's sheer size, it still lacks a well-developed road system, and large parts of its population rely on the Railway for passenger and goods transport. With shipment volume ever increasing between the advanced economies in Europe and the growing emerging markets in South-East Asia, Russian Railways is perfectly situated to benefit greatly from the need of fast and reliable good transport between these countries. The company shares are held by the government of the Russian Federation.

Over its long history, Railways in Russia went through turbulent times. Historically, Russian Railways was initiating innovation processes by requesting their preferred manufacturers to deliver solutions for described problems (e.g. CJSC Transmashholding, ${ }^{6}$ Rostec State Corporation). Due to the importance of Russian Railways for Russia's development, its mission was to a large extent on stimulating the local production. Starting from the late 1980s though, maintenance and investment in innovative transport solutions were strongly neglected. Also, maintaining the capital-intensive infrastructure is very costly. The 85 thousand $\mathrm{km}$ of railway lines in the Russian Federation (more than half of Russia's railway tracks are electrified) requires regular modernization of railway infrastructure. Wear and tear of equipment means a large-scale need for replacement of contact wires and suspension cables. Here, innovative processes could make a major impact on the cost structure of the company. Hence, the national railway transport development strategy identified at least \$ 5119.5 billion rubles of investment needs for the period 20082015 and $\$ 6328.3$ billion rubles for $2016-2030$ for the modernization and development of the infrastructure and rolling stock. The Russian Railways' share should reach about a half of this spending.

Also, transport management is a weak point. More than 2000 rail carriers operate all over Russia (mostly affiliated to large state-owned companies or independent). Often, idle wagons are left somewhere on the tracks, which cannot be used for other transport.

Russian Railways recently initiated a number of innovation projects. Their in-house R\&D units, national and international collaboration and the help of their research and technology organizations enabled the company to successfully introduced innovations like:

- compressed natural gas turbines

- automatic driving system of high-speed trains with power saving functions

- traffic control technology based on intelligent systems, including advanced time management

- Satellite status monitoring technology infrastructure

- Security technology work stations on based on digital models of the way and satellite navigation.

- Technology interval traffic control based on track circuits

${ }^{6} 25 \%$ plus I share of CJSC Transmashholding belong to Russian Railways, another $25 \%$ plus I share is owned by Alstom. The rest of the shares are controlled by other Russian structures,

${ }^{7}$ This is without compensating for the cut-backs in investment during the economic crisis of 2008-2009. 


\section{Innovation management of russian railways}

The company's innovation strategy includes twelve priority areas: transportation management system, infrastructure, rolling stock, control system and traffic safety, disaster risk reduction, increased reliability and increase service life, high-speed and high-speed traffic, corporate quality management system, improving economic and energy efficiency, environmental protection, technical regulation, the introduction of innovative satellite and GIS technologies. However, special importance is given to projects that meet government priorities. Here, improving energy efficiency of the hardware is of great importance.

The innovation management system at Russian Railways had to become integrated into the corporate decision support system. Here, a major challenge of introducing a capable innovation management was to align the different planning levels, intellectual property management policies and the establishment of clear chain of command. The latter point is of prominent importance as management at different levels collaborates with the company's many partners. Here, ownership of projects were ascribed to key executives and competence centers.

Russian Railways formulates its strategic directions in an annual plan based on trends in science and technology, basic and applied research (mostly new technologies applied in other companies), feasibility studies, long-term development plans and prototypes. This planning activity involves all levels of management of the company, subdivisions, subsidiaries and third parties. The company created the position of the Head of Research and Technology for the group in charge of implementing the company's very own innovation program. The position is assisted by the department of technical policies which is in charge of the execution of the outlined development and gathering of intelligence. The department works closely with regional innovation development centers which were established in 2009. The company now holds weekly meetings on various aspects of innovation to quickly make joint decisions on important issues for the company.

To find a common language, Russian Railways agreed on a number of indicators which should monitor the company's progress. Top among these indicators rank energy efficiency measures in line with the Energy Strategy. Next rank indicators for the efficient deployment of fixed assets, the renewal of the locomotive fleet, but also the specific amount of traffic accidents or indicators for environmental performance (e.g. reducing the load on the environment, air emissions and wastewater discharges).
Since the start of the program in 201I, the bulk of the planned indicators of its effectiveness has been achieved. Problematic has proven the set of indicators on delivering within scheduled time or average speed of delivery of the consignment. Here, the company identified the slow turnover of freight cars largely due to activities of private carriers as their main problem. The company reports annually on the implementation of innovative development program to the Ministry of Economic Development of Russia.

The company is successfully tackling technology areas like control systems and traffic safety steel satellite technology in collaboration with Russian-based GLONASS. Moreover, innovation activities are carried out in close scientific cooperation with universities, institutions of the Russian Academy of Sciences, academic institutions, public corporations, the business community. Areas of critical technologies where the development gaps will not be easily closed through cooperation with existing partners require the transfer of technology from leading international and domestic companies. The major point here was the development of innovative rolling stock.

Russia's motor engineering has once been among the finest in the world, but fell behind during the 1980s. Today, Russian Railways still relies on the Russian diesel-electric engine D-49, produced and modified for over 40 years. Now, further incremental improvements are no longer feasible as the design is outdated.

"Look at our old D-49 Russian diesel engine. 40 years old, always modified to improve the engine. But there is nothing to squeeze out anymore. It's an old machine! Look, 40 years ago asynchronous traction motors were the latest thing. Now they are old. We have studied all of these engines, but the fact is that until recently, we could not build a reliable asynchronous traction motor ourselves."

Especially the energy efficiency of its hardware is a topic of great interest, given that over $6 \%$ of Russia's energy production is consumed by locomotives. Hence, it is the company's top priority to reduce specific energy consumption. ${ }^{8}$ Here, the most prominent success story is the introduction of the power turbine engine GTIh. Its 8500 $\mathrm{kW}$ gas turbine power is well-suited for non-electrified tracks in Siberia and the Far North to economically transport freight. Its operational costs are lower than traditional diesel fuel. Should the turbine fail, the locomotive still caries enough own energy through a battery for $80 \mathrm{~km}$ at a speed of $50 \mathrm{~km} / \mathrm{h}$. Furthermore, the use of gas-powered

${ }^{8}$ It seems unrealistic for the company to reduce energy consumption in absolute terms as the new rails built are being electrified. 
locomotives reduces emissions by the factor $4-$ which provides special advantages in major cities. In recent years, Russian railcars improved their technical performance, with increased axle load ( 25 ton or more) and resources that allow for increasing the mileage between depot repairs to 500 thousand kilometers. Despite all of these innovations, Russian Railways intended to establish high-speed railway lines between its major cities. Such expertise though were not to be found within its own network.

\section{First step - joining the high-speed club}

In Russia's west, population density is relatively high and big cities are very populous. The area is flat and very well suited for high-speed trains. Russian Railways was considering developing such a train by itself, but decided that it is not worth the effort.

"If we would have started to design such a train from scratch, it would have taken us $10-15$ years. We are hopelessly behind, and investing everything anew would make sure we would never catch up".

Instead, a quick upgrade of the hardware was necessary. The additional cash-flow generated can then be used to finance other innovation projects. In order to increase the technology level, Russian Railways screened for best practices all over the world and studied them in great depth. After a call for interest, Siemens was chosen to be the most suitable provider. The first contract was signed on May 18 2006 between Russian Railways and Siemens over eight highspeed trains (Eur 276m) and a 30-year service contract (Eur $300 \mathrm{~m}$ ). Based on the design of the ICE3, the trains "Sapsan" (peregrine falcon) provide space for 600 passengers and connected first Moscow to Saint Petersburg and since July 2010 Moscow to Nizhny Novgorod. The train's engines operate on $3 \mathrm{KV} \mathrm{DC}$ and $25 \mathrm{kV} 50 \mathrm{~Hz} \mathrm{AC}$ and the gauges were adjusted to the 13 inch Russian standard.After the first test phase, tough, it became clear that the ICE3 was not fully suitable to Russia's harsh climate conditions.

"The first time we tested the trains in winter, it was not really cold. But then, temperature fell below -30 . Tracks began to form, by $5 \mathrm{~mm}$ sometimes. The wheels they used so far were completely unsuitable. Together, we had to find a solution... This was a quite complicated process. First, we had to establish the weaknesses of the current design. Then, our scientists and engineers worked intensively with Siemens"

As described, the doors didn't close due to heavy snow-fall. A second - probably much more severe problem - arose when temperature started to fall below -40 degrees $C$. The wheels could adjust to slight movements of the tracks which contracted and started to change form. The Italian producer could not provide a solution and there was a need for a new wheel. As a starting point, the original wheels were changed on the ones from decommissioned Russian trains while a team of Russian and German scientists began working on the new wheels.

What started off like a simple purchase order from an international company turned into a multi-staged collaborative innovation process. After a period of experimentation, a reliable solution to the problem was found. These common research efforts resulted in the registration of not less than 26 joint patents. The high occupations rates of over $80 \%$ proved the high speed train connection to be very successful.

The automatic train control system that Russian Railways uses is in turn entirely of Russian origin. It is very precise, although Russia is the only country where high-speed trains move within the same track as local trains and freight trains.

I would say that our automatic train control systems are to some extent better than in Europe. Russian high-speed trains don't arrive late as they do in Europe'). The control system is entirely Russian. The only thing we did not buy is our control system - our brains so to say. The control system on trains is based on our satellite communication system and thereby entirely different to the European solution. Here, we don't lag behind. In fact, we even surpass Europe. Our trains are very much on time! They always run on dedicated lines".

\section{Second step - an international event fast forwards innovation}

With Siemens, Russian Railways successfully partnered with a technology leader. The cooperation was further facilitated by good relations between the governments of Russia and Germany. A logical consequence was extending this cooperation with Siemens into modernizing local passenger trains, which no longer served their purpose. In 2009 Russian Railways and Siemens signed a contract for 38 new German-produced trains for the Olympic Games in Sochi. This time, the collaboration should reach a more integrated manufacturing level. These trains should be produced locally and technology transfer to Russia should be part of the deal.

"The Germans were willing to share their technology. Others did not show the same intentions. This was one of the reasons why we decided to go with Siemens. Now, everything is agreed and validated by the two parties. In $2014,35 \%$ of the train will be produced in Russia, and the remaining part in Germany. Scientists and engineers now work together. But we also have to focus on the economic side of the project". 
Step-by-step, the Russian contribution to the train will increase and should reach $80 \%$ of local manufacturing by 2017. ${ }^{9}$ For this purpose the Russian group Sinara and Siemens AG set up the joint venture Ural locomotives in 2011 in Verhniaya Pyshma (Russia). Again here, the company developed a new version of Siemens' Desiro train, the Desiro RUS. The electric commuter train based on the $1520 \mathrm{~mm}$ broad gauge was called Lastochka (Swallow). A newly created engineering centre facilitates technological innovations and technology transfer.The first 18 trains were put in service in January 2013.

One serious obstacle to replacing old local trains depends on regional budgets, which might not be enough for the moment to purchase the new trains and Russian Railways hopes for substantial support from federal funds. In 2014 Russian Railways plan a further purchase of 16 trains manufactured in Russia which will replace the currently used local trains.

"The ones for Sochi are already purchased and paid. That's national budget. For other purchases, we talk about regional funds. And as soon as it is from the regional budgets, their decision makers are ready to buy cheap chunk..."

\section{Third step - the future}

Another major impulse for improvements of the equipment comes from new developments of raw material deposits. In the rather highly populated west, electricity supply is well-developed. In the vast majority of the country, though, diesel engines are of vital importance. For heavy transport, the over 40 year old D49 is still in use but requires replacement. As the D49 is highly inefficient, there was increasing public support for the manufacturing of new generation diesel engines. ${ }^{10}$

"Now they found Coal in the Amur region. This could give a positive impulse as the coal will have to be transported. Our locomotive production is a problem. Asynchronous motors are fine, but we need a new diesel engine"!
For this project, Russian Railways attempt to co-develop new diesel engines and use it on local platforms. In 2012, Russian Railways placed an order with JSC Transmashholding to supply 10 Russian-produced locomotives equipped with diesel engines of MTU Friedrichshafen GmbH (Germany). By the end of 2015 an engineering centre will be established to design new diesel engines and manage the whole production cycle of diesel engines in Russia. This new engineering centre will focus on the transfer of specific technologies from more than one supplier. For example, the company Knorr will provide break systems and establish a joint venture with JSC 'Federal Freight' (a subsidiary of Russian Railways) to manufacture and maintain break equipment for locomotives and other rail transport.

The probably most innovative project of Russian Railways targets the development of 'smart stations' including automatic maintenance systems. Such smart stations are established in Germany and other countries, and Russian Railways attempts to use the experience of Deutsche Bahn. To finance its implementation, the company struggles to receive 50 million Euros from the European Bank for Reconstruction and Development. Also, the construction of high-speed railway lines (HSRL) - from Moscow to St. Petersburg (HSRL I Project) and from Moscow to Kazan (and further to Ekaterinburg) is in planning." The construction of HSRL will allow travel four times faster from Moscow to Kazan and seven times faster from Moscow to Nizhniy Novgorod. Its commercial viability still needs to be proven. Considering the low level of salaries in Kazan and Nizhniy Novgorod, questions remain about demand for high price railway tickets.

\section{Analysis of STI cooperation of Russian Railways}

The move towards partnering with Siemens was not easily made. The primary port of call was with their previous suppliers of equipment. Unfortunately, these producers were not up to the technology that Russian Railways was seeking and most likely could not meet the requirements.
${ }^{9}$ Of course, such cooperation is still profitable for Siemens, because Russian Railways will have to acquire components for trains from Germany.

${ }^{10} \mathrm{~A}$ specific subprogram in the Federal targeted programme 'National technological base' (The Russian Government order of April 2I, 20I I N7I0-r).

\footnotetext{
"Information agency RZD partner.com (http://www.rzd-partner. com/). According to the survey, conducted by the sociological company 'The Public Opinion Foundation', such projects are in great demand. They are supported by $86 \%$ respondents from Kazan, 79\% from Moscow, 78\% from Nizhniy Novgorod, and $72 \%$ from Saint Petersburg.
} 
"Previously, if these were not met, the order still went to the best proposal. This procedure was no longer good enough for Russian Railways. We needed to put more pressure on the producers. We put a call up to make clear that if our Russian producers cannot deliver, we'll buy them in Germany or in France. However, you can't simply buy locomotives. You have to make them fit for Russia!"

Russian Railways made it clear that they were willing to break with practices and leave their well-established innovation chain. It was no longer necessary to pick the best local producer, but you could now shop around. Still, simply buying the technology is not possible, but the use of the hardware in Russia needs adjustments. This was initially an expensive necessity, but turned into a much welcomed source of new knowledge.

"For us, we prefer to buy the technology. This technology though is not readily available. Therefore, we have to develop the technology further. The more components we can use that have already been developed, the better it is. With such cooperations, we can at least increase the speed of development. Still, we have to bear the cost. And such developments are expensive".

This necessity to adjust technologies to the Russian environment also excluded the possibility of buying a license. An innovation manager explains:

"Most of these technologies have been developed by companies that don't belong to us. Though, as we are big, we could initiate the innovation process by specifying the technical requirements for the locomotives... We could also have simply bought the license. The problem, though, is that improvements on these technologies belong to the owner. Hence, we needed the rights. Good engineers find it easy to communicate with each other. They clear problems fairly quickly as they arise".

The move towards collaboration on R\&D management was almost forced upon Russian Railways as Siemens did not have a solution readily at hand.As the classical and - so to say - standardized channels of knowledge transfer were off the table, alternative methods had to be found in negotiations on R\&D collaboration. The formal R\&D collaboration was agreed upon in the second series of collaboration. Such negotiations are long and take up a lot of time. For the development of the Desiro RUS train: in 2009 an agreement was signed to procure 38 German made trains; half a year later a memorandum was signed to jointly produce and service trains in Russia; in September 2010 the contract for the procurement of 16 Russian-made trains was finalized; a year later the joint venture was started in Verhniaya Pyshma (Russia). Thus, it is a long process, and for each stage the profitability is under scrutiny.
Here, the government involvement into the company offered relief. The political relationship between the two countries played a facilitating role when negotiating such large R\&D projects. Therefore, cooperations between Russian Railways and Siemens have been made possible only through the good relationship between the President of Russia and the Chancellor of Germany. A model train has been developed by both Russian Railways and Siemens which now travels across Russia which had a very strong promoting effect. Thereby, Russian Railways also appeals to young talent in the regions to join their workforce ('When seeing such a modern train young people become willing to work in Russian Railways').

As described earlier, these expenditures on new technology and its adjustment are pushing the company to its limit, with the consequence that building new (or reconstruction of old) railway tracks for the Baikal-Amur Mainline (BaikaloAmurskaya magistral, BAM) and Trans-Siberian Railway (Transsibirskaya Magistral) is already very difficult. Large amounts of goods (including coal) require transport to customers inside the country. After long debates, the company managed to convince government to co-fund these projects when the Presidency of Russia announced the investment priority of 'infrastructure projects that pay'. This is very much in line with the experience of the Sapsan trains, which generate immediate income streams.

"People don't understand how railways in Russia operate. A lot of information is in the media, which is not always right. We would need more money..."

To master the new demands on their equipment, Russian Railways is now developing new diesel locomotives and carrier wagons. To do so, the company now switched to an open innovation paradigm and invites different contributors in. This was largely facilitated through the prior positive experiences. ${ }^{12}$

"So, we are looking to develop different technologies like break systems. This is also a joint development. We need these breaks for freight trains. The information about various projects are openly available. Not just with the German partners."

\footnotetext{
${ }^{12}$ I50 billion rubles for that purpose will come from the National Welfare Fund which is a part of Federal budget supposed to cofinance pension savings of population and to support Pension Fund of Russia. http://press.rzd.ru/smi/public/ru?STRUCTURE_ $I D=2 \&$ layer_id $=5050$ \&refererLayerld $=5050 \& \mathrm{id}=28239 \mathrm{I}$ [Accessed July 15, 20I4].
} 
Among specific problems, Russian Railways mention difficulties with the technology transfer in collaborating with foreign partners. International partners have limited interest in sharing their technologies with emerging economies ('Nobody wants to sell its technologies to the those who lag far behind'). Typically, foreign companies sell licenses on the usage of technology without allowing modification. For a buyer, such acquisitions are of limited use, as the technology needs to be adapted to local conditions. Hence it is crucial to gain beneficial negotiations including the exchange of specialists in IP and engineers. This will result in a risk reduction for both parties.

\section{Conclusions}

The paper was initiated through the authors' interest in innovation processes in Russian SOE. While most of them struggle to close the widening technology gap, this paper presented the experience of Russian Railways. The successful international STI cooperation of Russian Railways is untypical for Russia's SOE. Instead of investing in own R\&D, the company is acquiring technology which allows the introduction of state-of-the-art transport services. The necessary need to adjust the technology to the Russian environment started a learning process in innovation management. The example shows that the fear of dependence on foreign components producers is only partly justified. Undoubtedly, innovative development usually takes time and money, and the success is not always secured. The price of this strategy maybe high, but it triggers a wave of new developments.

We identified the following methodology in Russian Railways' strategy, which other companies might find useful:

I. Identification of a starting project with high commercial potential and limited innovation capacity.

2. Positive experiences and established partnerships are the starting ground for further development. Here now, the gradual localization of technological processes inside the country, including the set-up of joint ventures are a viable option.

3. Embedding best technological solutions, giving priority to high-end technologies in most areas, allows bridging the gap between technology leaders and followers.

4. Focusing on several big socially important projects may help to get additional government funding and support, and win the trust of people.
Basing on authors' own observations and the analysis of available information, additional recommendations might be mentioned how to improve a company's innovative strategy. Many Russian SOE struggle with embedding innovation into business processes. The innovation development program of Russian Railways is much focused on technological part, and innovation is understood as a separate activity disconnected from other company's processes. ${ }^{13}$ At the same time, business processes at Russian Railways have many bottlenecks (over-centralization of management, expensive and out-of-time procurement of products and components, lack of coordination between departments, outdated regulatory documents and norms, huge amounts of reporting documentation). These problems are to great extent interconnected and derive from the existing organisational structure and management culture. Also, in Russian SOE, there is a systemic problem with motivating people. In Soviet times, working at the railway was perceived by people as a privilege. Now there are urgent problems in staff motivation. Firstly, young talented workers see the employer as unappealing, which leads to a widening generation gap and interferes with experience transfer, high pressure on lower level managers and a non-stimulating work environment. Despite the downsides, the emergence of a more innovative culture will solve most of the aforementioned problems.

This paper gives in inside view on Russian Railways' innovation strategy and derives universal advice for other SOEs. We hope that this in-depth case study will trigger further research on similar corporations to allow for a comparative approach to innovation strategies from outside the very unique Russian environment.

\footnotetext{
${ }^{13}$ This can be observed from the goals of innovation strategy (part 2 of the innovation development program). http://rzd.ru/static/ public/ru?STRUCTURE_ID=666 [Accessed July I5, 20I4].
}

ISSN: 07I 8-2724. (http://www.jotmi.org) 


\section{Acknowledgements}

Support from the Basic Research Program of the National Research University Higher School of Economics is gratefully acknowledged.

\section{References}

AGHION, P., HOWITT, P. (1990).A model of growth through creative destruction (No. w3223). National Bureau of Economic Research.

AMSDEN,A. (1989).Asia's Next Giant: South Korea and Late Industrialization. Oxford University Press, New York.

BARKEMA, H. G., Shenkar, O., Vermeulen, F. and Bell, J. H. (1997). Working abroad, working with others: How firms learn to operate international joint ventures. Academy of Management journal, 40(2), pp. 426-442.

BROWN, S. L., Eisenhardt, K. M. (1997).The art of continuous change: Linking complexity theory and time-paced evolution in relentlessly shifting organizations. Administrative science quarterly, 42, pp. I-34.

CHEN, L.-Ch. (2009). Learning through informal local and global linkages: The case of Taiwan's machine tool industry. Research Policy, 38(3), pp. 527-535.

CHESBROUGH, H.W. (2003). Open innovation: The new imperative for creating and profiting from technology. Harvard Business Press.

CHIANG, J.-T. (1989). Technology and alliance strategies for follower countries. Technological Forecasting and Social Change, 35(4), pp. 339-349.

CHOI,D.,Valikangas, L.(200I).Patterns of strategy innovation. European Management Journal, 19(4), pp. 424-429.

COHEN,W. M., Levinthal, D.A. (1990). Absorptive capacity: a new perspective on learning and innovation. Administrative science quarterly, 35(I), pp. I28-152.

DOBSON, W., Safarian, A.E. (2008). The transition from imitation to innovation: An enquiry into China's evolving institutions and firm capabilities. Journal of Asian Economics, 19(4), pp. 30I-3II.

EISENHARDT, K. M., Martin,J.A. (2000). Dynamic capabilities: what are they? Strategic management journal, $2 \mathrm{I}$ (I0-I I), PP. II05-II2I.
ENKEL, E., Gassmann, O. (2010). Creative imitation: exploring the case of cross-industry innovation. R\&D Management, 40(3), pp. 256-270.

GASSMANN, O. (2006). Opening up the innovation process: towards an agenda. R\&D Management, 36(3), pp. 223-228.

HAGEDOORN, J., Schakenraad, J. (1994). The effect of strategic technology alliances on company performance. Strategic management journal, I5(4), pp. 29I-309.

KIM, L. (1997). Imitation to Innovation: The Dynamics of Korea's Technological Learning. Harvard Business School Press, Boston.

LAURSEN, K., Salter,A. (2006). Open for innovation: the role of openness in explaining innovation performance among UK manufacturing firms. Strategic management journal, 27(2), pp. $|3|-\mid 50$.

LEONARD-BARTON, D. (1992). Core capabilities and core rigidities: A paradox in managing new product development. Strategic management journal, I3, pp. I I I-I 25.

MALAGAS, K., Kourousis, K., Baxter, G., Nikitakos, N., Gritzalis, S. (20/3). The Introduction of Innovative Services in a State Owned Airline: A Case Study of an IT Migration Project, Journal of Technology Management and Innovation, 8(2), pp. 74-83.

MANSFIELD, E. (1988). Industrial R\&D in Japan and the United States:A comparative study. The American Economic Review, 78(2), pp. 223-228.

NELSON, R.R., Winter, S.G. (1982). An Evolutionary Model of Economic Change. Cambridge. Mass: Harvard University Press.

NIOSI, J. (1999). The Internationalization of Industrial RD-Fr. Research Policy, 28(2), pp. 107-II8.

PILLER, F.T.,Walcher, D. (2006).Toolkits for idea competitions: a novel method to integrate users in new product development. R\&D management, 36(3), pp. 307-318.

PRAHALAD, C. K., Hamel, G. (1990). The core competence of the corporation. Boston (MA).

ROMER, P. M. (1990). Endogenous technological change. Journal of Political Economy, 98(5), pp. 7I- 02.

ROSENBERG, N. (1994). Exploring the Black Box: Technology, Economics, and History, Cambridge University Press: Cambridge, England. 
ROY, S., Sivakumar, K., and Wilkinson, I. F. (2004). Innovation generation in supply chain relationships: a conceptual model and research propositions. Journal of the Academy of Marketing Science, 32(I), pp. 6I-79.

SCHEWE, G. (1996). Imitation as a strategic option for external acquisition of technology. Journal of Engineering and Technology Management, I3(I), pp. 55-82.

TEECE, D. J. (2007). Explicating dynamic capabilities: the nature and microfoundations of (sustainable) enterprise performance. Strategic management journal, 28(I3), PP. |3|9-1350.

TEECE, D. J., Pisano, G., and Shuen, A. (1997). Dynamic capabilities and strategic management. Strategic management journal, I8(7), pp. 509-533.

VON HIPPEL, E. (1988). The Sources of Innovation. New York: Oxford University Press.

WANG, C. L., Ahmed, P. K. (2007). Dynamic capabilities: A review and research agenda. International Journal of Management Reviews, 9(I), pp. 3I-5I.

ZOLLO, M., Winter, S. G. (2002). Deliberate learning and the evolution of dynamic capabilities. Organization science, 13(3), pp. 339-35I. 


\begin{tabular}{|c|c|c|c|}
\hline $\begin{array}{l}\text { Russian } \\
\text { SOE }\end{array}$ & R\&D partners & Form of cooperation & Project details \\
\hline \multirow[t]{4}{*}{ Gazprom } & $\begin{array}{l}\text { Wintershall Holding AG (BASF } \\
\text { subsidiary, Germany) }\end{array}$ & $\begin{array}{l}\text { Joint venture with } \\
\text { Gazprom mining Urengoi Ltd } \\
\text { (Achimgaz) }\end{array}$ & $\begin{array}{l}\text { Commercial mining and production of natural } \\
\text { gas and condensate from the Achimov layers } \\
\text { (since 2008) }\end{array}$ \\
\hline & $\begin{array}{l}\text { Statoil (Norway) } \\
\text { Total SA (French Group) }\end{array}$ & $\begin{array}{l}\text { Joint venture (Shtokman } \\
\text { Development AG) }\end{array}$ & $\begin{array}{l}\text { Development of the Shtokman offshore } \\
\text { gas-condensate field (In August } 2012 \text { Statoil } \\
\text { exited from the project) }\end{array}$ \\
\hline & $\begin{array}{l}\text { Royal Dutch Shell (Netherlands, } \\
\text { Great Britain), Mitsui, Mitsubishi } \\
\text { (Japan) }\end{array}$ & Joint venture (Sakhalin Energy) & $\begin{array}{l}\text { The offshore extraction of hydrocarbons } \\
\text { Sakhalin-2 (since 2006). }\end{array}$ \\
\hline & $\begin{array}{l}\text { Russian-German Energy Agency } \\
\text { RUDEA (Germany) }\end{array}$ & $\begin{array}{l}\text { Long-term agreement with } \\
\text { Gazpromenergosberezhenie } \\
\text { and JSC INTER RAO UES in } \\
\text { the field of energy } \\
\text { conservation and efficiency }\end{array}$ & $\begin{array}{l}\text { Construction of new and reconstruction of } \\
\text { existing boilers, generating stations, thermal } \\
\text { and electrical networks, infrastructure facilities } \\
\text { using advanced German technologies as well as } \\
\text { Russian equipment, materials and services }\end{array}$ \\
\hline AvtoVAZ & $\begin{array}{l}\text { TRW Automotive Gmbh } \\
\text { (Germany) } \\
\text { T akata-Petri AG (Germany, Japan) } \\
\text { Robert Bosch GmbH (Germany) }\end{array}$ & $\begin{array}{l}\text { Agreement } \\
\text { Protocol on technical } \\
\text { cooperation }\end{array}$ & $\begin{array}{l}\text { The projects with TRW Automotive Gmbh and } \\
\text { Takata-Petri AG is related to automobile safety } \\
\text { systems, and the project with Robert Bosch } \\
\text { GmbH concerns engineering of ABS and ESP } \\
\text { systems for LADA }\end{array}$ \\
\hline \multirow[t]{4}{*}{$\begin{array}{l}\text { Aeroflot Rus- } \\
\text { sian Airlines }\end{array}$} & $\begin{array}{l}\text { Boeing (USA) } \\
\text { Airbus (Europe) }\end{array}$ & Agreement & $\begin{array}{l}\text { Purchase of aircraft, system components and } \\
\text { equipment on a regular basis }\end{array}$ \\
\hline & $\begin{array}{l}\text { Flight simulator producers: } \\
\text { CAE (Canada) } \\
\text { RP Aero Systems (UK) }\end{array}$ & Agreement & $\begin{array}{l}\text { Purchase of flight simulators for Aeroflot } \\
\text { Aviation School }\end{array}$ \\
\hline & Lufthansa Technik (Germany) & $\begin{array}{l}\text { Five-year contract (since } \\
\text { 2009) }\end{array}$ & $\begin{array}{l}\text { Technical support and maintenance of the } \\
\text { Aeroflot aircraft }\end{array}$ \\
\hline & $\begin{array}{l}\text { Suppliers of IT solutions: } \\
\text { Lufthansa Systems (Germany), SAP } \\
\text { (Germany) }\end{array}$ & Long-term agreement & $\begin{array}{l}\text { Optimization of finance, implementation of ERP } \\
\text { systems }\end{array}$ \\
\hline \multirow[t]{7}{*}{$\begin{array}{l}\text { Russian } \\
\text { Railways }\end{array}$} & Siemens (Germany) & $\begin{array}{l}\text { Joint venture } \\
\text { (Ural locomotives) }\end{array}$ & $\begin{array}{l}\text { Joint engineering and manufacturing of electric } \\
\text { trains and electric freight locomotives }\end{array}$ \\
\hline & Alstom (France) & Joint venture (TRTrans) & Manufacturing of electric passenger trains \\
\hline & $\begin{array}{l}\text { Tatravagonka } \\
\text { (Slovakia) }\end{array}$ & $\begin{array}{l}\text { Joint venture with Trans- } \\
\text { maschholding (Transmasch) }\end{array}$ & $\begin{array}{l}\text { Manufacturing of flat wagons for carrying } \\
\text { large-tonnage containers and of multifunctional } \\
\text { covered trucks of new type }\end{array}$ \\
\hline & Bombardier (Canada) & Joint venture (ELTEZA) & $\begin{array}{l}\text { Manufacturing of systems of railroad } \\
\text { automation and telemechanics }\end{array}$ \\
\hline & Finmeccanica (Italy) & $\begin{array}{l}\text { Memorandum of } \\
\text { understanding and roadmap }\end{array}$ & $\begin{array}{l}\text { Modernization of automatic train control } \\
\text { systems }\end{array}$ \\
\hline & $\begin{array}{l}\text { MTU Friedrichshafen } \mathrm{GmbH} \\
\text { (Germany) }\end{array}$ & $\begin{array}{l}\text { Joint venture with } \\
\text { Transmaschholding }\end{array}$ & $\begin{array}{l}\text { Manufacturing of diesel engines of new } \\
\text { generation }\end{array}$ \\
\hline & Knorr-Bremse (Germany) & $\begin{array}{l}\text { Joint venture with JSC 'Federal } \\
\text { Freight' (a subsidiary of } \\
\text { Russian Railways) }\end{array}$ & $\begin{array}{l}\text { Manufacturing and maintenance of brake } \\
\text { equipment for locomotives and other rail } \\
\text { transport }\end{array}$ \\
\hline
\end{tabular}

Annex I.STI cooperation between Russian and foreign corporations. Source: ISSEK/HSE

ISSN: 07 I 8-2724. (http://www.jotmi.org)

Journal of Technology Management \& Innovation (c) Universidad Alberto Hurtado, Facultad de Economía y Negocios. 